\title{
Effect of heavy metal cations on the activity of cathepsin D (in vitro study)
}

\author{
Alicja Karwowska', Radosław Łapiński², Marek Gacko², Ewa Grzegorczyk ${ }^{1}$, \\ Joanna Żurawska², Jan K. Karczewski ${ }^{1}$ \\ ${ }^{1}$ Department of Hygiene and Epidemiology, Medical University of Bialystok, Poland \\ ${ }^{2}$ Department of Vascular Surgery and Transplantation, Medical University of Bialystok, Poland
}

\begin{abstract}
We studied the effect of heavy metal cations: $\mathrm{Fe}^{2+}, \mathrm{Cu}^{2+}, \mathrm{Zn}^{2+}, \mathrm{Cd}^{2+}, \mathrm{Hg}^{2+}, \mathrm{Pb}^{2+}$ on the activity of cathepsin D in human aorta homogenate and blood serum. The concentration of cations was $1 \mathrm{mmol} / \mathrm{l}$. Hemoglobin was the cathepsin D substrate. The activity of cathepsin D was determined at $\mathrm{pH} 3.5$. Only $\mathrm{Hg}^{2+}$ cations inhibit the activity of cathepsin D. Cations $\mathrm{Hg}^{2+}$ damage lysosomes and release cathepsin $\mathrm{D}$ from these organelles. (Folia Histochemica et Cytobiologica 2012, Vol. 50, No. 3, 432-435)
\end{abstract}

Key words: cathepsin D, lysosomes, heavy metals

\section{Introduction}

Cations, $\mathrm{Fe}^{2+}, \mathrm{Cu}^{2+}$ and $\mathrm{Zn}^{2+}$ are natural components of the organism, while $\mathrm{Cd}^{2+}, \mathrm{Hg}^{2+}$ and $\mathrm{Pb}^{2+}$ can only be found in a state of intoxication. Whichever pathway heavy metals take to reach the body, they pass through the blood and come into contact with plasma proteins, morphotic components and vascular endothelial cells [1-3]. In arterial disorders, changes in the content of these metal cations have been observed both in plasma and in vascular wall lesions [4-10]. Agarwal et al. found that high levels of serum cadmium are associated with cardiovascular and cerebrovascular disease [11]. Poręba et al. observed that exposure to lead can be associated with increased blood pressure and accelerated progression of atherosclerosis [12]. Moreover, they found that higher blood concentrations of lead and cadmium are independent risk factors for the incidence of arterial hypertension in subjects chronically exposed to heavy metals $[13,14]$. Other researchers have claimed that

Correspondence address: A. Karwowska,

Department of Hygiene and Epidemiology,

Medical University of Bialystok,

Mickiewicza Str. 2c, 15-089 Białystok, Poland;

tel.: + 48857485560 ;

e-mail: alicja.karwowska@umb.edu.pl mercury can also be a risk factor for hypertension and atherosclerosis [15]. In hypertension, atherosclerosis and aneurysm, changes in the activities of lysosomal proteolytic enzymes, e.g. cathepsin $\mathrm{D}$, occur in blood plasma and arterial walls [16-20].

The study objective was to determine the effect of heavy metal cations of variable ionic radius $\left(\mathrm{Fe}^{2+}\right.$, $\left.\mathrm{Cu}^{2+}, \mathrm{Zn}^{2+}, \mathrm{Cd}^{2+}, \mathrm{Hg}^{2+}, \mathrm{Pb}^{2+}\right)$ on the activities of cathepsin D in human aorta homogenate and blood serum, and on their release from liver lysosomes.

\section{Material and methods}

Hemoglobin, (Difco Laboratories, USA); Folin-Ciocalteu reagent, (Merck, Germany); Bradford reagent and trichloracetate acid, (Sigma, USA); biuret reagent and metal cations (chlorides): $\mathrm{Fe}^{2+}, \mathrm{Cu}^{2+}, \mathrm{Zn}^{2+}, \mathrm{Cd}^{2+}, \mathrm{Hg}^{2+}, \mathrm{Pb}^{2+},(\mathrm{POCh}$, Gliwice, Poland).

The whole abdominal aorta homogenate from ten organ donors was prepared according to the method described previously [21]. Serum was obtained from ulnar vein blood collected from ten healthy subjects. The blood was incubated for $1 \mathrm{~h}$ at $37^{\circ} \mathrm{C}$ and centrifuged $\left(1,500 \times \mathrm{g}, 30 \mathrm{~min} .2^{\circ} \mathrm{C}\right)$.

Metal cations solutions $(0.05 \mathrm{ml})$ at a concentration $10.0 \mathrm{mmol} / \mathrm{l}$ (in control $0.15 \mathrm{~mol} / \mathrm{K} \mathrm{KCl}$ for homogenate and $0.15 \mathrm{~mol} / \mathrm{l} \mathrm{NaCl}$ for serum) was added to $0.35 \mathrm{ml}$ homogenate and $0.35 \mathrm{ml}$ serum, $\mathrm{pH} 7.5$. Following a $30-\mathrm{min}$ preincu- 
bation at $37^{\circ} \mathrm{C}$, the samples were adjusted to $\mathrm{pH} 3.5$. The pH 3.5 samples were supplied with $0.1 \mathrm{ml}$ of $6 \%$ hemoglobin (pH 3.5) and incubated at $37^{\circ} \mathrm{C}$ for 6 hours (both homogenate and serum). The reaction was discontinued by adding $0.1 \mathrm{ml}$ of $10 \%$ trichloracetic acid. Precipitated samples at time 0 were treated as control. In the supernatant obtained through centrifugation, the amount of released tyrosine was determined [22].

Lysosomes-containing homogenate of six rabbit livers was prepared following the method described previously [23]. A $0.15 \mathrm{ml} 8.0 \mathrm{mmol} / \mathrm{l}$ cation solution (in control 0.15 $\mathrm{mol} / \mathrm{l} \mathrm{KCl}), \mathrm{pH} 7.5$, was added to $1.05 \mathrm{ml}$ of this homogenate (pH 7.5), and incubated for $30 \mathrm{~min}$. at $37^{\circ} \mathrm{C}$. When $\mathrm{pH}$ 5.0 was obtained, the samples were centrifuged $(1,500 \times \mathrm{g}$, $30 \mathrm{~min} ., 2^{\circ} \mathrm{C}$ ). The obtained cytosol was adjusted to $\mathrm{pH} 3.5$, and the activities of cathepsin $\mathrm{D}$ were determined as described above. Their activities were also investigated in whole liver homogenate [21].

The activity of cathepsin D was expressed as the level of released tyrosine (nmol) per one gram of tissue and per hour in homogenate and cytosol, and per milliliter and per hour in serum.

The Bradford method was used to determine protein in homogenate and cytosol [24]. Serum protein was determined using the biuretic method [25].

\section{Results}

Only $\mathrm{Hg}^{2+}$ cations inhibited the activities of cathepsin $\mathrm{D}$ in the aorta homogenate (Table 1). The mean protein content in the aorta homogenate was $12.7 \mathrm{mg} / \mathrm{g}$ tissue.

$\mathrm{Hg}^{2+}$ cations also inhibited the activity of cathepsin D in blood serum (Table 2). The mean serum protein was $72.4 \mathrm{mg} / \mathrm{ml}$.

The $\mathrm{Hg}^{2+}$ cation released the highest amounts of cathepsin D from hepatocyte lysosomes (Table 3 ). The release of this cathepsin was accompanied by a slight release of protein.

\section{Discussion}

Divalent metal cations bind to the carboxyl, amino, disulphide and thiol groups of proteins [26-29]. With carboxyl groups, they form salt-type bonds, with ami-

Table 1. Influence of heavy metals cations on activity of aorta homogenate cathepsin D

\begin{tabular}{|l|c|c|}
\hline \multirow{2}{*}{ Cation [1 mmol/l] } & \multicolumn{2}{|c|}{ Cathepsin D } \\
\cline { 2 - 3 } & Tyr [nmol/g/h] & Inhibition (\%) \\
\hline $\mathrm{Fe}^{2+}$ & $709.2 \pm 70.2$ & 3.9 \\
\hline $\mathrm{Cu}^{2+}$ & $710.5 \pm 71.8$ & 3.8 \\
\hline $\mathrm{Zn}^{2+}$ & $724.3 \pm 72.3$ & 1.8 \\
\hline $\mathrm{Cd}^{2+}$ & $715.2 \pm 72.3$ & 2.9 \\
\hline $\mathrm{Hg}^{2+}$ & $629.8 \pm 69.3^{*}$ & 14.6 \\
\hline $\mathrm{Pb}^{2+}$ & $728.6 \pm 71.0$ & 1.2 \\
\hline $\mathrm{KCl}, 0.15 \mathrm{~mol} / \mathrm{l}($ control) & $737.2 \pm 73.0$ & 0.0 \\
\hline
\end{tabular}

* $\mathrm{p}<0.05$ compared to the control

Table 2. Influence of heavy metals cations on activity of serum cathepsin D

\begin{tabular}{|l|c|c|}
\hline \multirow{2}{*}{ Cation [1 mmol/l] } & \multicolumn{2}{|c|}{ Cathepsin D } \\
\cline { 2 - 3 } & Tyr [nmol/g/h] & Inhibition (\%) \\
\hline $\mathrm{Fe}^{2+}$ & $47.3 \pm 4.8$ & 8.9 \\
\hline $\mathrm{Cu}^{2+}$ & $48.5 \pm 4.9$ & 6.5 \\
\hline $\mathrm{Zn}^{2+}$ & $51.7 \pm 5.4$ & 0.4 \\
\hline $\mathrm{Cd}^{2+}$ & $50.2 \pm 5.3$ & 3.3 \\
\hline $\mathrm{Hg}^{2+}$ & $37.7 \pm 3.9^{*}$ & 27.4 \\
\hline $\mathrm{Pb}^{2+}$ & $51.0 \pm 5.6$ & 1.7 \\
\hline $\mathrm{NaCl}, 0.15 \mathrm{~mol} / \mathrm{l}$ (control) & $51.9 \pm 5.2$ & 0.0 \\
\hline
\end{tabular}

*p $<0.05$ compared to the control

Table 3. Influence of heavy metals cations on the release of cathepsin D from lysosomes of liver

\begin{tabular}{|l|c|c|c|c|}
\hline \multirow{2}{*}{ Cation [1 mmol/l] } & \multicolumn{2}{|c|}{ Cathepsin D } & \multicolumn{2}{c|}{ Protein [mg/g], (\%) } \\
\cline { 2 - 5 } & Tyr [nmol/g/h] & Release (\%) & {$[\mathbf{m g} / \mathbf{g}]$} & Release (\%) \\
\hline $\mathrm{Fe}^{2+}$ & $86.6 \pm 8.2$ & 12.7 & $2.4 \pm 0.2$ & 6.3 \\
\hline $\mathrm{Cu}^{2+}$ & $89.5 \pm 8.4$ & 13.3 & $2.5 \pm 0.2$ & 6.5 \\
\hline $\mathrm{Zn}^{2+}$ & $84.2 \pm 8.3$ & 12.5 & $2.6 \pm 0.3$ & 6.9 \\
\hline $\mathrm{Cd}^{2+}$ & $87.6 \pm 7.9$ & 12.9 & $2.5 \pm 0.3$ & 6.7 \\
\hline $\mathrm{Hg}^{2+}$ & $98.8 \pm 8.9 *$ & 14.9 & $2.2 \pm 0.2$ & 5.9 \\
\hline $\mathrm{Pb}^{2+}$ & $77.7 \pm 8.0$ & 11.6 & $2.7 \pm 0.2$ & 7.1 \\
\hline $\mathrm{KCl}, 0.15 \mathrm{~mol} / \mathrm{l}($ control) & $80.9 \pm 7.6$ & 12.0 & $2.7 \pm 0.3$ & 7.1 \\
\hline $\mathrm{Whole} \mathrm{homogenate}$ & $674.2 \pm 65.8$ & 100.0 & $38.0 \pm 4.1$ & 100.0 \\
\hline
\end{tabular}

*p $<0.05$ compared to the control 
no and disulphide groups they form complex bonds, and with thiol groups they form sulphides.

Binding of metal cations to carboxyl groups of the Asp33 and Asp231 residues of the catalytic site of cathepsin D plays a major role in the inhibition of its activity [30]. This refers mainly to the mercuric cation, which shows strong affinity for carboxyl groups.

The affinity of metal cations for proteins depends on the dimension of their ionic radius and standard potential [31]. The $\mathrm{Hg}^{2+}$ cation, with the ionic radius of $102 \mathrm{pm}$ and $\mathrm{Hg}^{2+} / \mathrm{Hg}$ standard potential of $+0.851 \mathrm{~V}$, exhibits the strongest inhibitory effect on cathepsin D [32]. Cations with a greater or smaller ionic radius and higher and lower standard potential do not inhibit cathepsin D activity.

Increased permeability of the lysosomal membranes is caused by damage to the structure of membrane lipids and proteins directly by metal cations and reactive oxygen species formed through the action of these cations [3, 33-39]. This leads to cathepsin release from lysosomes. However, the activity of cathepsin D secreted to cytosole is reduced by the part inactivated by the respective cations.

Specific binding proteins (metallothionein, transferrin, ferratin, ceruloplasmin and others) prevent the toxic action of heavy metal cations [40-42]. The metal binding exogenous compounds include ethylenodiaminotetraacetate acid, diethylenotriaminopentaacetic acid, $\mathrm{N}$-acetylocystein, penicillamine and deferoxamine [43-45]. The concentrations of heavy metal cations used in the current experiment resembled those in the blood and tissues of intoxicated subjects [46]. Their in vitro effects do not differ from the ones observed in the acute intoxication of laboratory animals, in which cathepsin D activity was reduced both in blood plasma and in organs [34, 47, 48]. However, no such relationship was found in the wall of atherosclerotic or aneurysmatic arteries $[6,17,49,50]$.

\section{Acknowledgements}

This study was supported by a grant from the Medical University of Bialystok, no. 113-39900 LM.

\section{References}

1. Goyer RA, Clarkson T. W. 2001. Toxic effects of metals, in: Toxicology. The basic science of poisons, ed. C.D. Klaassen. McGraw-Hill, New York. 811.

2. Nogaj E, Kwapuliński J, Nogaj P, Szczygiet Ł. Arterial vessels as biomarkers of heavy metals exposure. Ann Acad Med Siles. 2006;60:290-296.

3. Poręba R, Gać P, Poręba M, Andrzejak R. Environmental and occupational exposure to lead as a potential risk factor for cardiovascular disease. Env Tox Pharm 2011;31:267-277.

4. Iskra M, Patelski J, Majewski W. Relationship of calcium, magnesium, zinc and copper concentrations in the arterial wall and serum in atherosclerosis obliterans and aneurysm. J Trace Elem Med Biol. 1997;11:248-252.

5. Gacko M, Głowiński S, Worowska A. The contents of zinc, magnesium, manganese, copper and iron in the wall of aortic aneurysm. Biul Magnezol. 1999;4:322-324.

6. Antonowicz-Juchniewicz J. Środowiskowy i zawodowy wptyw metali ciężkich na rozwój zmian patologicznych w naczyniach krwionośnych. Wyd. AM Wrocław, Wroclaw 2001.

7. Hukałowicz K, Borawska M, Gacko M, Guzowski A, Czyżewska E. The contents of copper in serum, arterial wall and parietal thrombus of patients with aortic abdominal aneurysm. Metal Ions Biol Med. 2004;8:456-459.

8. Nogaj E, Kwapuliński J, Nogaj P, Bogunia M, Ahnert B. Content of heavy metals in femoral arteries changed by atherosclerotic process in persons living in the industrial Silesian region. Med Środ. 2005;8:117-126.

9. Socha K, Borawska MH, Gacko M, Guzowski A, Markiewicz R. Diet and the content of cadmium in the blood, arterial wall and parietal thrombus of the patients with aortic abdominal aneurysm. Bromat Chem Toksykol. 2005;37(Suppl.):51-55.

10. Karamova LM, Larionova TK, Basharova GR. Criteria of ecologic safety for serum levels of heavy metals in humans. Med Tr Prom Ekol. 2010;6:21-23.

11. Agarwal S, Zaman T, Tuzcu EM, Kapadia SR. Heavy metals and cardiovascular disease: results from the National Health and Nutrition Survey (NHANES) 1999-2006. Angiology. 2011;62:422-429.

12. Poręba R, Poręba M, Gać P, Andrzejak R. Ambulatory blond pressure monitoring and structural chan ges In carotid arterie In normotensive Wolkers occupationally expose to lead. Hum Exp Toxicol. 2011;30:1174-1180.

13. Poręba R, Gać P, Poręba M, Andrzejak R. The relationship between occupational exposure to lead and manifestation of cardiovascular complications In persons with arteria hypertension. Toxicol Appl Pharmacol. 2010;249:41-46.

14. Poręba R, Gać P, Poręba M et al. Relationship between chronic exposure to lead, cadmium and manganese, blond pressure values and incidence of arterial hypertension. Med Pr. 2010;61:5-14.

15. Skoczyńska A, Jędrejko M, Martynowicz H et al. The cardiovascular risk In chemical faktory workers expose to mercuty vapor. Med Pr. 2010;61:381-391.

16. Yamada E, Hazama F, Amano S, Sasahara M, Kataoka H. Elastase, collagenase and cathepsin D activities in the aortas of spontaneously hypertensive and renal hypertensive rats. Exp Molec Pathol. 1986;44:147-156.

17. Gacko M, Chyczewski L. Activity and localization of cathepsin B, D and G in aortic aneurysm. Int Surg. 1997;82:398-402.

18. Gacko M, Ostapowicz R, Chrostek L, Worowska A, Kordecki K. Activity of enzymes with different subcellular localization in the blood plasma of patients with aortic aneurysm. Med Sci Monit. 2005;11:CR211-CR213.

19. Jormsjo S, Wuttge DM, Sirsjo A et al. Differential expression of cysteine and aspartic proteases during progression of atherosclerosis in apolipoprotein E-deficient mice. $\mathrm{Am}$ J Pathol. 2002;161:939-945.

20. Petersen E, Wagberg F, Angquist KA. Proteolysis of the abdominal aortic aneurysm wall and the association with rupture. Eur J Vasc Endovasc Surg. 2002;23:153-157.

21. Karwowska A, Gacko M, Worowska A, Krupkowska A. Tissue fragmentation for biochemical studies. Bromat Chem Toksykol. 2006;39(Suppl.):199-202.

22. Greczaniuk A, Roszkowska-Jakimiec W, Gacko M, Worowska A. Determination of cathepsin D activity in blood plas- 
ma using hydrochloric acid denaturate haemoglobin. Diagn. Lab. 2000;36:97-101.

23. Gacko M, Głowiński J, Skrzydlewska E, Worowska A, Głowiński S. Activity of enzymes of various subcellular localization in cytosol obtained after cell organelle precipitation at pH 5,0. Annal Acad Med Bialostocensis. 1996;41:341-346.

24. Bradford MM. A rapid and sensitive method for the quantitation of microgram quantitation of protein utilizing the principle of protein-dye binding. Anal Biochem. 1976;72:248-254.

25. Gornall AC, Bardawill CJ, David HM. Determination of serum proteins by means of the biuret reaction. J Biol Chem. 1949;177:751-766.

26. Vallee BL, ULMER DD. Biochemical effects of mercury, cadmium and lead. Ann Rev Biochem. 1972;41:91-128.

27. Tukendorf A. Proteins and peptides binding heavy metals. Post Bioch. 1989;35:141-153.

28. Haugaard N. Reflection on the role of thiol groups in biology. Ann NY Acad Sci. 2000;899:148-158.

29. Manahan SE. Toxicological chemistry and biochemistry. PWN, Warszawa 2006; 267.

30. Minarowska A, Gacko M, Karwowska A, Minarowski Ł. Human cathepsin D. Folia Histochem Cytobiol. 2008;46,23-38.

31. Worowski K. Mechanism of action of proteolytic enzymes. Post Hig Med Dośw. 1978;32:467-491.

32. Bielański A. Basis of inorganic chemistry. PWN, Warszawa 2002.

33. Yonaha M, Ohbayashi Y, Ichinose T, Sagai M. Lipid peroxidation stimulated by mercuric chloride and its relation to the toxicity. Chem Pharm Bull. 1982;30:1437-1442.

34. Żak J, Chociłowska W. Effect of cadmium on lysosomes permeability in the liver. Bromat Chem Toksykol. 1987;20:214-215.

35. Stohs SJ, Bagchi D. Oxidative mechanisms in the toxicity of metal ions. Free Rad Biol Med. 1995;18:321-336.

36. Stohs SJ, Bagchi D, Hassoun E, Bagchi M. Oxidative mechanisms in the toxicity of chromium and cadmium ions. J Environ Pathol Toxicol Oncol. 2001;20:77-88.

37. Havelaar AC, De Gast IL, Snijders S. Characterization of a heavy metal ion transporter in the lysosomal membrane. FEBS Lett. 1998;436:223-227.
38. Yu ZQ, Persson HL, Eaton JW, Brunk UT. Intralysosomal iron: a major determinant of oxidant-induced cell death. Free Rad Biol Med. 2003;34:1243-1252.

39. Goch A, Goch JH. Lead-induced pathomechanism of hypertension. Pol Merk Lek. 2005;18:351-353.

40. Fowler BA. Biological roles of high affinity metal-binding proteins in mediating injury. Comments Toxicol. 1989;3:27-46.

41. Vasak M, Hasler DW. Metallothioneins: new functional and structural insights. Chem Biol. 2000;4:177-183.

42. Coyle I, Philcox JC, Carey LC, Rofe AM. Metallothionein: the multipurpose protein. Cell Med Life Sci. 2002;59:627-647.

43. Chvapil M, Ryan JN, Brada Z. Effects of selected chelating agents and metals on the stability of liver lysosomes. Biochem Pharmacol. 1972;21:1097-1105.

44. Kostyniak PJ, Clarkson TW. Role of chelating agents in metal toxicity. Fund Appl Toxicol. 1981;1:376-380.

45. Łukasiak J, Jamrogiewicz Z, Jackowska D, Ożarowski A, Krasicki A. Zastosowanie kwasu wersenawego i jego soli w terapii ostrych i przewlekłych zatruć metalami. Ord Lek. 2006;6:26-30.

46. Schulz M, Schmold A. Therapeutic and toxic blood concentrations of more than 500 drugs. Pharmazie. 1997;52:895-910.

47. Davidson SJ. Metal-ion effects on proteolysis and stability in secondary lysosomes of mouse kidney. Biochim Biophys Acta. 1975;385:163-172.

48. Skrzydlewska E, Worowski K, Moniuszko-Jakoniuk J, Gałażyn-Sidorczuk M. Ascertation of distribution and determination of proteinases activity in hepatocytes in cadmium intoxication. Acta Toxicol. 1994;2:83-88.

49. Ohkawara S, Kaji T, Yamamoto C, Fujiwara Y, Sakamoto M, Kozuka $\mathrm{H}$. Interaction between cadmium and zinc in the production and sulfation of glycosaminoglycans in cultured bovine vascular endothelial cells. J Toxicol Environ Health. 1996;47:183-193.

50. Skoczyńska A. Miażdżycowe działanie ołowiu i kadmu. Czynniki Ryzyka. 1999;4:20-25.

Submitted: 9 December, 2011

Accepted after reviews: 26 January, 2012 